\title{
Interdependence versus Truth and Justice: Lessons from Reconciliation Processes in Maluku
}

\author{
Diah Kusumaningrum•
}

\begin{abstract}
Truth commissions and trials have been applauded as the way to move on from a violent past. Yet, some post-conflict societies managed to move toward reconciliation without the presence, or the effective presence of such formal institutions. This article discusses a number of lessons learned from Maluku, where reconciliation took the interdependence path. Taking on an interpretive, emic approach, it elaborates on the sites and mechanisms of interdependence. It argues that interdependence can be as viable as truth and justice procedures in bringing about reconciliation.
\end{abstract}

\section{Keywords:}

interdependence; reconciliation; Maluku conflict.

\begin{abstract}
Abstrak
Menurut literatur, rekonsiliasi hanya akan berhasil jika ada komisi kebenaran dan pengadilan ad hoc. Kenyataannya, beberapa masyarakat pasca konflik mampu menjalani proses rekonsiliasi tanpa kedua institusi formal tersebut. Tulisan ini mengangkat kasus Maluku, di mana rekonsiliasi ditempuh melalui jalur interdependensi. Berangkat dari pendekatan interpretivis dan emik, tulisan ini mendiskusikan situs dan mekanisme interdependensi. Tulisan ini berargumen bahwa jalur interdependensi bisa mengantarkan masyarakat pasca konflik menuju rekonsiliasi, layaknya jalur kebenaran dan keadilan.
\end{abstract}

\section{Kata Kunci:}

interdependensi; rekonsiliasi; konflik Maluku.

\section{Introduction}

Truth commissions and trials have been applauded as the way to move on from a violent past. Accordingly, post-conflict experiences lacking these formal procedures are usually treated as cases in which no reconciliation takes place - wherein the troublesome past is dealt through forgetting and pardoning, resulting in a collective amnesia and a culture of impunity. Otherwise, they are treated as

\footnotetext{
- Lecturer of Department of International Relation, Faculty of Social and Political Science, Universitas Gadjah Mada

Email: diahkei@ugm.ac.id
}

cases in which reconciliation takes place in a suboptimal manner, thus likely to impose serious challenges to democracy and long-term peace. $^{1}$

I wish to take a different position. I contend that, under certain circumstances, post-conflict societies can indeed move toward reconciliation without the presence, or the effective presence, of truth commissions or trials. One exemplary case is Maluku, Indonesia, where reconciliation takes a distinct

\footnotetext{
See Hayner (2002), Avruch (2010), Braithwaite, et.al. (2010), Popovski and Serrano (2012), and van Klinken (2014).
} 
path: interdependence. By interdependence, I refer to the path to reconciliation that John Paul Lederach (1997), Johan Galtung (2001), and contributors to Antonia Chayes and Martha Minow's (2003) edited volume refer to as peace, joint reconstruction, and coexistence, respectively. The literature suggests that this path to reconciliation is anchored in the notion that former enemies have a common, connected future (Lederach, 1997: 29), is motivated by pragmatic needs rather than moral imperatives (Gardner Feldman, 1999), is less costly than resolving conflicts through formal (legal) procedures (Smith, 1989: 386), makes it too costly "both in political and human terms, for conflict to be carried out by violent means" (Ackermann, 1994: 245), and is essentially a series of narrative shifts from "since we are enemies, hostility is the only option" to "since we are one and we need each other, hostility would definitively be foolish" (Sluzki, 2010: $59-62)^{2}$.

As any other phenomenon, reconciliation carries different meanings to different people. Believing that a good study of reconciliation needs to cogitate these meanings seriously, my qualitative study takes on an interpretive, $\mathrm{emic}^{3}$ approach. Through participant observation, in-

\footnotetext{
2 Carlos Sluzki (2010: 59-62) talks of interdependence as one of the six stages between open conflict and reconciliation. The stages and the dominant narrative surrounding each are (1) confrontation - "hostility is the only option", (2) truce - "we are ready for hostile acts when needed", (3) collaboration - "hostilities are a fall back option", (4) cooperation - "hostilities would be a major disadvantage", (5) interdependence - "we need each other, hostility would definitely be foolish", and (6) integration - "we are one."

3 When taking an emic (instead of an etic) approach, a researcher tries to understand a phenomenon through the viewpoints of the research subjects. Here, prior theories and assumptions are put aside to allow participants and data to "speak for themselves" and to let themes, patterns, and concepts emerge. For further discussions on emic and etic perspectives, see Headland, Pike, and Harris (1990), Willis (2007), Yin (2010), and http://isites.harvard.edu/icb/icb.do?keywo rd=qualitative\&pageid=icb.page 340911
}

depth interviews, and focus group discussions, ${ }^{4}$ I looked into "everyday reconciliation" in Maluku. In doing so, I gained insights to reconciliation as vernacular practices, as it is understood and experienced on a day-to-day basis by people in Maluku. These insights would have been entirely overlooked by studies that narrowly associate reconciliation with formal truth and justice procedures. ${ }^{5}$

This article presents some lessons learned from reconciliation processes in Maluku. It starts off with a snippet of the Maluku case and what reconciliation means to Malukans. Then, it discusses the four sites where it is exercised: ceremonial, neighborhood, functionalquotidian, and narrative. Subsequently, it teases out the three mechanisms that underpin it: emphasis on social roles over religious affiliations, display of remorse and forgiveness, and creation of focal points for peace-proving that interdependence is indeed a viable path to reconciliation. While its adoption may indicate some reluctance to take on the truth and/ or justice paths to reconciliation, I maintain that interdependence, at least in the case of Maluku, does not abandon truth and justice altogether. In this very case, truth is pursued in a limited manner, for the specific purpose of trust building, whereas justice is pursued in a future-oriented manner, for the specific purpose of conflict prevention.

\section{Reconciliation in Maluku}

January 1999 saw the beginning of violent communal clashes between Christians and Muslims in Maluku. ${ }^{6}$ Over 2,000 incidents of

\footnotetext{
${ }^{4}$ In addition to conducting 57 in-depth interviews and seven focus group discussions, I studied interview transcripts from Ambon Database Pilot Study ( $\mathrm{n}=160)$ and Ambon Database $(n=240)$.

5 Some notable studies that break away from tradition and highlight local pursuits of truth and justice are those of by Heonik Kwon (2006), Birgit Braeuchler (2009), and Alexander Laban Hinton (2010).

6 In this paper, the term "Christian" denotes followers of the Protestant faith, and is selected over "Protestant"
} 
communal violence were recorded between January 13, 1999 and February 13, 2002 (Barron, Azca, \& Susdinarjanti, 2012: 12), the day representatives of both parties signed a truce known as the Malino II Declaration. The conflict led to spatial segregation of Christians and Muslims, which, in nearly all villages, members of the minority faith group were forced to flee. It also led to a severe disruption of freedom of movement, where Christians were confined in Christian quarters and Muslims were confined in Muslim quarters. It claimed over 6,000 lives, with more than 7,000 people injured, and nearly 29,000 buildings destroyed (ibid.), as well as caused the displacement of over 500,000 people (ICG, 2000). Additionally, 39 incidents of communal violence took place after Malino II, altogether claiming the lives of 367 people (ibid.). Most of them happened shortly after the signing of the truce, but the most notable were those of 2004 and 2011. ${ }^{7}$

In Maluku, efforts toward reconciliation relied neither on truth commissions nor trials. Although a fact finding mission was launched by the Indonesian National Commission on Human Rights (Komisi Nasional Hak Asasi Manusia - Komnas HAM), ${ }^{8}$ its report only glosses over some general information that have nevertheless been publically known and is not in any way a full record of the various narratives surrounding the Maluku conflict. Although over 850 arrests were made by 2000, trials could not be held because personnel of the

to remain close to the vernaculars in Maluku, where Protestants are referred to as "Kristen" and Catholics as "Katolik." Most Protestants in Maluku are followers of Gereja Protestan Maluku (GPM - Maluku Protestant Church). Traditionally part of the Dutch Reformed Church, GPM adheres to Calvinism.

7 For more details on the causes and dynamics of the Maluku conflict, see Adam (2009; 2010), Azca (2006), Bartels (2003), Braithwaite and Dunn (2010), Panggabean (2004; 2014a; 2015), Sidel (2008), and van Klinken $(2001 ; 2007)$.

8 OnJanuary 14,2000, Komnas HAM formed a Commission for Human Rights Violation Investigation and Mediation in Maluku (Komisi Penyelidik Pelanggaran Hak Asasi Manusia dan Mediasi di Maluku). legal system had fled and prisons had broken down (Braithwaite \& Dunn, 2010: 158-159). Even after the legal system was restored, trials of several leaders of Christian and Muslim organizations were held in regular criminal courts, not in special human rights trials. Moreover, such processes were not extended to ordinary citizens despite their involvement in the violent events. In other words, the processes of healing and "moving forward" were neither based on truth nor justice; there are neither official accounts of "who did what to whom, where, when, and how" nor official decisions on "who pays what to whom, where, when, and how." ${ }^{\text {" }}$

Keeping in mind that the literature ${ }^{10}$ champions formal truth -and justice- seeking procedures, it is easy to dismiss Maluku as a case in which reconciliation did not take place or did take place in a suboptimal manner. ${ }^{11}$ However, a careful look into the dynamics of Christian-Muslim relations in post-conflict Maluku revealed that Malukans - both at the elite and grassroots level - do meaningfully engage in reconciliation processes, through the interdependence path.

Building upon Lily Gardner Feldman's (1999) notion that interdependence is motivated by pragmatic, rather than moral, imperatives, I specify that one strong driving force for

\footnotetext{
9 I use this phrase to cover a wide range of justice procedures, including, but not limited to, paying compensation, serving time in prison, and being banned from certain privileges.

${ }^{10}$ For general reading on reconciliation and transitional justice, see Avruch (2010), Chapman (2009), Daly and Sarkin (2007), Dancy, Kim, and Wiebelhaus-Brahm (2010), Galtung (2005), Kymlicka and Bashir (2008), Lederach (1997), Licklider and Bloom (2007), Long and Brecke (2003), Olsen, Payne, and Reiter (2010), Popovski and Serrano (2012), Pouligny, Simon, and Schnabel (2007) and Staub (2006).

${ }^{11}$ Skepticism about "non-truth" and "non-justice" post-conflict arrangements in Indonesia can be found in Braithwaite, et.al. (2010) and van Klinken (2014). Meanwhile, those who are optimistic, despite the lack of truth- and justice- seeking procedures in Maluku, include Ali-Fauzi (2013) and Panggabean (2014b).
} 
interdependence is the need to restore "normalcy. ${ }^{12 "}$ Throughout my research, I came across ample narratives on the urgency of restoring the systems distorted by the Maluku conflict: health, education, transportation, sanitation, agriculture, fishery, security, governance, and communication systems, to name a few. Mothers insisted that children child-soldiers included-should be able to return to school, customers demanded unrestricted access to all traditional markets and all shops within and beyond the segregation lines, traders stressed the importance of reopening their supply lines and of reestablishing clienteles from both the Christian and Muslim sides, drivers of public transportation were eager to reopen cross-village routes, workers needed the banks to run again to withdraw their monthly salary, doctors emphasized that both communities should have access to all medical facilities, religious leaders saw it important that churches and mosques return to their function as places of worship and not be used as warmobilization centers, youths were restless about not having enough music and sporting events they could attend to, and so on. They were adamant about recovering "life before the 1999 clash" and the motive for this goes beyond moral imperatives of living harmoniously; it is mainly grounded in practical needs to go on with a decent life. They understood that ending spatial segregation and reinstating freedom of movement is central to restoring such systems which they are contingent upon for reestablishing and sustaining ChristianMuslim cooperation.

Attempts to initiate the above activities capitalized on pre-conflict intergroup camaraderie among friends, relatives, neighbors, colleagues, and classmates. They started with a few Christians, or Muslims, reaching out to members of the other faith group whom

\footnotetext{
${ }^{12}$ I am aware that the term "normalcy" is loaded and has contested meanings - hence the quotation marks.
}

they have developed rapport with before 1999 to jointly facilitate perjumpaan (encounters). Over time, the encounters expanded in terms of frequency, intensity, and the number of people involved. Sustained by superordinate goals (Sherif, 1958) to restore normalcy and consistent to the contact hypothesis (Allport, 1954) and intergroup contact theory (Pettigrew, 1998), they generated space for deconstructing stereotypes, checking rumors, learning other "versions" of past events, etc., as well as for developing realistic empathy (White, 1984) among Christians and Muslims. ${ }^{13}$

From an emic viewpoint, it is clear that the numerous Christian-Muslim activities to restore normalcy are parts of reconciliation processes: they are conscious and voluntary acts that mark a departure from the violent past and signify restored relationships with "the other side." What is interesting is that Malukans themselves were not so keen on the term rekonsiliasi. ${ }^{14}$ When asked "what does rekonsiliasi mean to you?" almost no respondents provided straightforward "definitions." I found at least four groups of answer to the question, each pointing at resentment, prerequisites, indicators, or procedures of reconciliation.

The first one, amply found in early 2000s, reflects "no rekonsiliasi" attitudes. It underlines the deep resentments that Malukans had against the term rekonsiliasi, as it invokes the idea of turning one's head away from the atrocious past, of not taking issues with the wrongdoings of the other group, of betraying one's own group. Here, the narratives surrounding rekonsiliasi include "How can you expect us to reconcile with those who have killed our family members?" "Reconciliation means letting them get away with what

\footnotetext{
${ }^{13}$ Bringing in theories on social capital and communal conflicts, it is plausible to say that while bridging civic associations (Putnam, 2000; Varshney, 2002) seem to have failed to prevent the Malukan communal conflict, they play a crucial role in fostering reconciliation through the interdependence path.

${ }^{14}$ This is the Indonesian term for "reconciliation."
} 
they did!" and "If we reconcile with them, it means we are betraying our deceased family members and our religion." Individuals who reached out to "the other" were indeed labeled as Judas, sell-outs, traitors, converts, spies, human-headed snakes, apostates, and halal darahnya (someone whose blood is considered permissible by Islamic law to be spilled).

The second group represents the "rekonsiliasi, but only if" attitudes, mostly found in the months and years following the 2002 Malino II Conference. Here, Malukans had become more open to the term and idea of rekonsiliasi. They no longer see rekonsiliasi as unthinkable, but as contingent upon the fulfillment of a number of prerequisites, mostly genuine apologies from perpetrators to victims. Unfortunately, both Christians and Muslims at this point were convinced that culpability lies entirely on the other side, that they were purely victims, and that their participation in violence was merely self-defense. As stated by a Muslim respondent, "I think, in order to achieve peace, Christians should admit that they indeed planned the conflict and should apologize to Muslims." Mirror perceptions were found among the Christians as well.

The third group consists of the "rekonsiliasi is when" responses, which marks what Malukans think the indicators of a reconciled society should be. An overwhelming majority underlined that rekonsiliasi is achieved when Christians and Muslims are back to living the basudara ${ }^{15}$ ethics. Others expressed that rekonsiliasi occurs when all displaced Christians and Muslims can return to their village, or when people no longer have desire for revenge. This emphasis on indicators signify a departure from perceiving rekonsiliasi as contingent upon apologies from the other faith group. This third group of responses, along with that of the

\footnotetext{
${ }^{15}$ Malukans believe that they, regardless of religious, ethnic, and class affiliations, are basudara - that is, the bond as "siblings." The basudara ethics has been passed on through generations over the centuries.
}

fourth, dominates the narratives on rekonsiliasi in the late 2000s and onwards.

The fourth group is comprised of "rekonsiliasi through" responses, suggesting the ways rekonsiliasi should be pursued. Here, most respondents underlined that rekonsiliasi should be organik - that is, generated genuinely among Christians and Muslims at the grassroots level, not imposed by the state or Christian/Muslim elites. More specifically, some respondents mentioned that at the grassroots level, rekonsiliasi can be nurtured through peace economy, collective labor (gotong royong), sports, music, and exchange activities. Two statements from Rev. Jacky Manuputty, one of the main peace activists in Maluku, fall into this category. First, he mentioned that rekonsiliasi is like weaving a colorful straw mat (menganyam tikar pandan) done by interlocking differently colored straws in such a way that they hold and support each other. Second, he mentioned that rekonsiliasi work is like eating hot porridge, where one should start from the sides of the bowl, one scoop at a time. To him, rekonsiliasi is about bringing together the various Christian and Muslim networks to initially discuss and work on "mundane" dayto-day issues and only then gradually engage them in more "sensitive" issues (Manuputty, Interview, January 2014).

It is crucial to underline that all of the above respondents participated in interdependencebased activities. In other words, even those who explicitly said that they would not reconcile with the other, as it means betraying their family and friends, or as it needs to be preceded by apologies from perpetrators, take part in various Christian-Muslim activities to restore normalcy. Positivistic approaches to the study of reconciliation are likely to take at face value the statements that Malukans rejected rekonsiliasi. Meanwhile, an emic approach calls for a more thorough examination. It encourages researchers to look at the meanings, symbolism, and performativity surrounding Christian- 
Muslim collaborations. It sheds light on actual reconciliation practices that were concealed by anti-rekonsiliasi statements.

The temporal variation of what rekonsiliasi means in Maluku sheds light on when and why Malukans started to embark upon (the interdependence path of) reconciliation. In a separate piece, I argue that the reasons for this pertain to (1) the adoption of provokator narratives - in which Malukans shift the ultimate blame from "the other faith group" to an "elusive, unidentifiable third party", (2) the idea that everyone is complicit - wherein Malukans accept that everyone, including themselves and their coreligionists, is guilty, be it by commission or omission, and (3) vivid memories of peace - wherein memories of harmonious Christian-Muslim relations over the centuries, of being basudara, overcomes memories of violence. ${ }^{16}$ What is more relevant to this article is to notice the shift from subjects tying up rekonsiliasi with notions of truth and justice (as in the first and second group of responses) to narrating rekonsiliasi as practices of interdependence (as in the third and fourth group of responses) - of which the next section delves into.

\section{Interdependence and Its Four Sites}

Upon thorough observation of the various perjumpaan and Muslim-Christian collaborations, I identified four sites in which interdependence occurs: ceremonial, neighborhood, functional-quotidian, and narrative. ${ }^{17}$

\footnotetext{
${ }^{16}$ It is elaborated in my doctoral dissertation (2015), why and how Malukans managed to embark upon interdependence - thus affording to bypass truth- and justice- seeking paths of reconciliation. In this paper, I focus on the "how" and merely state the "why."

17 These sites should not be seen as being mutually exclusive. Meetings of adat leaders, for example, are located at the ceremonial, neighborhood, and functional-quotidian sites altogether. Similarly, Christian-Muslim music collaborations are part of interdependence-based activities at both the functionalquotidian and narrative sites.
}

Ceremonial site. Activities at the ceremonial site brought together those who are perceived as influential and as representations of certain groups within the society. The Search Conference for Maluku ${ }^{18}$ (March 2000), the series of BakuBae workshops ${ }^{19}$ (AugustDecember 2000), and the Malino II Conference ${ }^{20}$ (February 2002) fall under this category, as they aimed at facilitating dialogues among prominent religious and community leaders of Maluku.

The initial hours, sessions, or days of the meetings went by with participants faulting the members of the other faith group for having incited communal violence. Convinced of their side's victimhood, as well as of the other side's malice, participants strongly refused to "make peace with the other." Nevertheless, they understood that in order to move towards normalcy they needed to mutually resolve a number of issues. These include IDPs, health, education, media, trauma healing, infrastructure, radicalization, security, and governance issues - all of which are dependent upon actions that ends the violence and reestablishes freedom of movement. Here, both

${ }^{18}$ This was the first meeting to bring together representatives of the Christian and Muslim communities since the outbreak of the Maluku conflict. It was attended by more than 50 participants and was jointly organized by The British Council and the Center for Security and Peace Studies of Gadjah Mada University (CSPSUGM). For security reasons and to enable more relaxed Christian-Muslim exchanges, the conference was held outside of Maluku, namely Bali, where the local population is predominantly Hindu. For details, see Hadar (2000).

${ }^{19}$ BakuBae started off with three workshops: August 2000 in Jakarta, October 2000 in Bali, and December 2000 in Yogyakarta. Its other activities include polling, facilitating profession/occupation-based meetings, campaigns, as well as audiences with leaders of formal religious and state institutions. For details, see Malik (2003).

${ }^{20}$ Sponsored by the Coordinating Minister for Economic and Industrial Affairs, Jusuf Kalla, Malino II Conference had the highest profile of all Christian-Muslim meetings. The conference was held on February 11-12, 2002, but was preceded by several exploratory consultations. For details, see Ernas (2006). 
sides made it clear to each other that what they aimed for was merely the cessation of violence, not peace nor reconciliation. This is consistent to the dominant view in early 2000s that while restoring normalcy is necessary, rekonsiliasi with the "other" means betrayal.

Neighborhood site. As indicated earlier, communal clashes had led to the displacement of approximately half a million people in Maluku (ICG, 2000). Many Christians had to flee from predominantly Muslim villages; many Muslims had to flee from predominantly Christian villages; many Christians and Muslims had to flee from mixed villages. ${ }^{21}$ Accordingly, a huge portion of restoring normalcy at the neighborhood site included facilitating the return of IDPs, reconstruction of buildings, and fostering good intergroup relations among neighbors. These activities brought together Christians and Muslims who live, or used to live, in the same village, as well as those who are bound by pela and/or gandong. ${ }^{22}$

In Wayame, a mixed village that remained intact throughout the Maluku conflict, ${ }^{23}$ Christians and Muslims formed Tim 20,24 which tasks included checking rumors and performing "in-group policing. ${ }^{25 "}$ In Nania,

${ }^{21}$ For more information on displacement in Maluku, see reports from the Internal Displacement Monitoring Centre (2011) and Jesuit Refugee Services (2006; 2013).

${ }^{22}$ Pela and gandong are part of adat (ethnic-based customary rules). Pela refers to intervillage alliances, while gandong refers to originating from the same line of ancestors. Given the intricate pela and gandong relations, it is very likely that most Malukan Christians are pela- or gandong-related to at least one Malukan Muslim, and vice versa. For a detailed explanation on pela, see Bartels (1985).

${ }^{23}$ Another mixed village in Maluku that remained intact throughout the conflict is Waraka (see Herin 2014).

${ }^{24}$ For more detailed illustration on Tim 20, see Al Qurtuby (2013) and Pariela (2008).

${ }^{25}$ I adopt the term "in-group policing" from James Fearon and David Laitin's (1996) study on interethnic cooperation. Here, Christian members of Tim 20 would punish Christian residents of Wayame taking part in violent acts, and Muslims member of Tim 20 would
Poka, and Rumah Tiga, Christians and Muslims extended security guarantees to each other, allowing for residents who had fled to return. On top of promising not to hurt each other, Christian residents pledged to protect their Muslim neighbors should Christian militias attack the village and Muslim residents pledged to protect their Christian neighbors in the event of attacks by Muslim militias. Additionally, both sides enthusiastically participated in collective labor to rebuild houses, churches, mosques, and other infrastructures destroyed during the conflict. Meanwhile, in many other villages, the processes of return and reconstruction were supported by the village's pela or gandong partner. In the predominantly Christian village of Waai, for example, residents received assistance, mostly in the form of labor, from their pela partner, the predominantly Muslim village of Morella. ${ }^{26}$

Functional-quotidian site. Apart from deaths, displacements, and physical damages, one major consequence of the communal violence in Maluku was strict spatial segregation, where freedom of movement was severely disrupted, meaning that Christians were confined in Christian quarters, Muslims in Muslim ones. This means that all public services as well as daily social economic activities became distorted. In the trade sector, spatial segregation "locked in" resources in Christian or Muslim areas - for example, fish,

punish Muslim residents of Wayame taking part in violent acts.

${ }^{26}$ Other examples include the reconstruction of places of worship in the predominantly Muslim village of Batu Merah, the predominantly Muslim village of Kailolo, and the predominantly Christian village of Tuhaha, which were assisted by each village's pela partner, respectively, the predominantly Christian village of Passo, the predominantly Christian village of Tihulale, and the predominantly Muslim village of Rohomoni. Other adat activities include panas pela, makan patita, vehe belan, and village-cleansing ceremonies. Braeuchler (2009c) and Laksono and Topatimasang (2003) provide detailed case studies on adat's role in reconciliation. Aladjai's (2013) novel also offers illustration on adat and reconciliation. 
vegetables, and rice (barang pasar) were only available in Muslim areas, whereas flour, sugar, cooking oil, and baby formula (barang toko) were only available in Christian areas. Money, too, was scarce in Muslim areas, given that all banks were located in Christian quarters. Christian children whose schools were located in Muslim quarters and Muslim children whose schools were located in Christian quarters lost access to education. Many people lost access to healthcare, as the nearest hospital, clinic, or doctor practice were located at a quarter "belonging" to the other faith group. Many lost their jobs as they could not trespass ChristianMuslim borders to get to where they were supposed to go; drivers of public transportation could not carry on with their usual inter village routes; journalists could only collect news in Christian or Muslim quarters, ${ }^{27}$ and so on.

Activities at the functional-quotidian site aim at restoring the above conditions through utilizing the specific training, skills, occupation, and networks attached to groups of colleagues or peers. A group of health workers built health centers at ChristianMuslim borders. Christian and Muslim traders met at border areas to exchange scarce goods. Minibus drivers paired-up and took turns - the Christian driver would be behind the wheel when passing by Christian villages, and vice versa. Journalists committed themselves to peace journalism and established Maluku Media Center, where they exchanged reports from Christian and Muslim quarters. Priests and ulamas organized interfaith dialogues, peace sermons, and "live-in" programs (where Christians spend some nights with a Muslim family and vice versa).${ }^{28}$ Christian and Muslim mothers and women banded together to take

\footnotetext{
${ }^{27}$ For more details on how the Maluku conflict affected the media, see Eriyanto (2003).

${ }^{28}$ For more examples of religious peace building, see Sandyarani (2014), Manuputty (2011), Wakano (2014), Toisuta (2014), Hendriks (2014), and Al Qurtuby (2013).
}

back their children from militias, to secure scholarships to keep children in school, to organize various trauma healing activities, to kick-start income-generating activities, and so on. ${ }^{29}$ Youths came up with rumorchecking mechanisms, organized music, sports, arts, blogging, travelling, photography and other events, provided emergency education programs in IDP camps, and so on. ${ }^{30}$ These are only a few examples of the many activities undertaken in the functional-quotidian site. ${ }^{31}$ It should be noted that many of the ChristianMuslim collaborations in this site were initiated in order to restore normalcy and only later on were modified to foster reconciliation.

Narrative site. More than a decade after the Maluku conflict, a number of movies, books, songs, and poems offer interpretations of the conflict and reconciliation processes in Maluku. One example is Cahaya Dari Timur: Beta Maluku, a movie about how football facilitated Christian-Muslim collaborations, which won the best picture at the 2015 Indonesian Film Festival. Irfan Ramly, the young Ambonese who wrote the screenplay, said that although the movie project was initially built around Sani Tawainella's life story, the characters and dialogues were redesigned in a way that incorporates the viewpoints of many Malukans regarding the conflict and reconciliation. "It underlines what everyone thinks and aspires, that is, to live peacefully and to live better" (Ramly, Interview, January 2015).

Other notable examples are documentaries made by Rifky Husain, Provokator Damai and Merah Saga, and one made by Victor Latupeirisa, Hiti-HitiHala-Hala-both Ambonese filmmakers. They portray the details of Christian-Muslim

\footnotetext{
${ }^{29}$ Soselisa (2007) wrote a Master's thesis about women as peacebuilding agents.

${ }^{30}$ Meinema's (2012) thesis provides a thorough analysis on the role of youths in peacebuilding.

${ }^{31}$ Carita Orang Basudara, an edited volume by Manuputty, Salampessy, Ali-Fauzi, and Rafsadi (2014) provides many examples of interdependence-based activities at the functional-quotidian site.
} 
collaborations in post-conflict Maluku: how they started, why they were considered as necessary, the processes, the strategies to overcome challenges, and so on.

Meanwhile, one of the most influential books that have ever been written about the conflict and post-conflict circumstances in Maluku is Carita Orang Basudara. It consists of 26 stories written by 25 Malukans - journalists, religious leaders, artists, activists, academicians, and politicians - reflecting upon ChristianMuslim relations before, during, and after the conflict. On the one hand, the stories reveal things that are private and personal. On the other hand, they appeal to something familiar to Malukans, that is, collective memories and experiences surrounding the conflict.

What stands out from the above movies and book - as well as from many other books, songs, and poems written by Malukans in the last decade - is the shared message that returning to the basudara life is the way to move forward. Enthusiastically celebrating Christian-Muslim collaborations that fall under interdependence, none of them advocate for the truth and/or justice paths of reconciliation..$^{32}$

What do we gain from identifying the four sites of interdependence? One thing is that it points at a gap in the literature, where there is a tendency to only locate reconciliation at the formal/national setting (i.e. Truth and Reconciliation Commission in South Africa and National Commission on the Disappearance of Persons in Argentina) and or local/neighborhood setting (i.e. gacaca in Rwanda and nahe biti in Timor Leste). ${ }^{33}$ This probably relates significantly to the notion that reconciliation involves out-of-ordinary activities

\footnotetext{
${ }^{32}$ By contrast, two novels written by non-Malukans hint at the need for pursuing formal truth and justice procedures. They are Jalan Lain ke Tulehu, by Zen RS and Kei: Kutemukan Cinta di Tengah Perang, by Erni Aladjai. In separate interviews (2015), both writers confirm their pro-formal-truth-and-justice viewpoint.

${ }^{33}$ See Olsen, Payne, \& Reiter (2010), Popovski and Serrano (2012), and Skaar, Gloppen and Suhrke (2005).
}

that are specifically designed for reconciliatory purposes. In spite of this, as we have learned from the Maluku case, day-to-day activities and narratives about those activities (respectively, the functional-quotidian and narrative sites) are also instances of reconciliation.

In addition to that, close observations of each site reveal the mechanisms that underpin interdependence, which is the focus of the next section.

\section{How Interdependence Works}

Upon meticulous observation of the various activities at the aforementioned ceremonial, neighborhood, functionalquotidian, and narrative sites, I suggest that interdependence functions through three mechanisms. First, it allows individuals to emphasize on their social roles rather than religious identity. It enables individuals to perform their roles as neighbors, mothers, youths, traders, customers, artists, doctors, journalists, bloggers, pela or gandong partners, members of the basudara community, and so on, rendering them opportunities not to identify themselves and be identified as Christians or Muslims at war. Such "identity change $^{34 " \prime}$ (Kelman, 2004) is easiest at the functional-quotidian site, relatively easy at the neighborhood site, plausible to portray at the narrative site, and most difficult at the ceremonial site. Undoubtedly, individuals enter the ceremonial site bearing the status as representatives of the Christian or Muslim community, which to a certain degree reasserts one's religious affinity.

Second, interdependence provides space for individuals to display their apologies

\footnotetext{
${ }^{34}$ Following Herbert Kelman's (2004) conceptualization of reconciliation as identity change, I suggest that individuals taking part in interdependence-based activities undergo a shift in their identity: from an identity of Christianity that is centered at the negation of Muslimhood and an identity of Muslimhood that is centered at the negation of Christianity, to an identity of Malukans.
} 
and forgiveness. In this case, participation in interdependence-based activities indicates a degree of remorse and willingness to forgive, as it is difficult to imagine that those who still hold animosities toward "the other" would participate in such activities. This indication is especially important given the "riot" and "mob violence" characteristic of the many communal clashes in Maluku, which makes it "next to impossible" to actually identify, reconnect with, and personally apologize to the very individuals whom one have hurt years ago. One respondent shared, "Everyone knows [about my violent past]. It is important for me to take part in various Christian-Muslim activities to show everyone that I have changed, that I regretted what I did" (Interview, January 2014). Another mentioned, "I knew the guys who destroyed my village. I understand that they did it because of 'the heat of the moment'. They never verbally apologized, but I know they are sorry. Their active participation in the various interfaith programs says so" (Interview, August 2014).

Third, interdependence leads to the creation of focal points ${ }^{35}$ for peace. Everyone is expected to know what participation in interdependence-based activities means: it generates an understanding that "I know that you know that I am sorry" and "you know that I know that you are sorry." This, in turn, fosters mutual security guarantees in the sense that everyone is confident that "the other side" is not interested in prolonging the violence. As illustrated by a respondent, "You are an outsider. What you see throughout this event are nice people coming together to celebrate peace. To us, it means more. We see former war commanders, former combatants, former enemies, and victims behaving as fellow citizens. By being here, each of us shows our commitment not to let that thing [communal

\footnotetext{
${ }^{35}$ By "focal point", I refer to Thomas Schelling's (1960: 57) idea of "each person's expectation of what the others expect him to expect to be expected to do."
}

violence] happen again. When they see us here, they become more confident in our commitment to peace. When we see them here, we become more confident in their commitment to peace" (Interview, January 2014).

The above mechanisms can be better understood by appreciating the performative aspects of interdependence. In other words, it is crucial to pay attention to the meanings that actors generate when they engage in this particular path of reconciliation. By openly taking part in formal Christian-Muslim meetings at the ceremonial site, in collective labor to repair houses, infrastructures, and places of worship, as well as in adat rituals at the neighborhood site, and in intergroup activities at the functional-quotidian site, an individual shows her willingness to distance herself from her religious identity and to redefine her social identities. She is, in a way, asking others to regard her and engage with her as a mother, a neighbor, a professional, etc. - not (merely) as a Christian or a Muslim. Her participation in the aforementioned interdependence-based activities also displays gestures of letting go of the violent past. Not only does she regret her and her coreligionists' contributions to the past communal violence, she also absolves members of the other faith group from their wrongdoings. Furthermore, she understands that the thought processes behind her participation in interdependencebased activities is understood and widely shared by others in her community. She knows that everyone knows that taking part in such activities signifies and strengthens commitments to peace.

\section{Folding in Truth and Justice into Interdependence}

As discussed throughout this paper, the interdependence path to reconciliation in Maluku is mostly driven by the pragmatic imperatives of restoring normalcy. By underlining Malukans' strong desires for 
normalcy, I do not mean to downplay the desires for truth and/or justice in Maluku. They, too, are robust. Nonetheless, the desires for normalcy and the desires for truth and justice seem to be at odds with each other. Truth and justice, together with amnesty and lustration, are paths of reconciliation that underline actors' involvements in past acts of violence. For these paths to work - that is, to issue public records on past atrocities, retribution and restitution schemes, official pardons, and bans to enter political offices - it is necessary to accurately identify who the perpetrators and the victims are. Such "singling out" is seen as counterproductive to restoring normalcy through interdependence, which hinges on collectiveness and on willingness of parties to collaborate with each other.

Again, an emic approach is useful in understanding how Malukans settle tensions between the desire for normalcy and the desire for truth and justice. Since restoring normalcy was considered to be more pressing time-wise, the pursuit of truth was predominantly carried out at the macro (national-provincial) level and geared toward identifying the grand scenario of the Maluku conflict and the outside actors masterminding it, rather than singling out at the micro (community) level by identifying who did what to whom, where, when, and how. Similarly, the pursuit of justice was geared toward demanding that the masterminds of the conflict be held accountable, rather than settling among ordinary people on who pays what to whom, where, when, and how. In other words, as suggested by the data collected from interviews (mine and that of Ambon Database Pilot Study's and Ambon Database's ${ }^{36}$ ), focus group discussions, and participant observation, over time, Malukans have become less interested in knowing who exactly killed their family members, burned their house, harassed them

\footnotetext{
36 Ambon Database Pilot Study and Ambon Database were put together by Samsu Rizal Panggabean and Ashutosh Varshney and funded by the Ford Foundation.
}

at checkpoints, etc. and are more interested in uncovering who among the military and civilian elites gave provokators the order to incite communal clashes in Maluku.

This is not to say that truth and justice paths of reconciliation are absent at the community level. As numerous interviews confirm, interdependence-based activities have elements of revealing the truth and observing justice. Upon developing a certain level of rapport, those taking part in these activities disclose their involvement in the conflict - perhaps not the entire story, but enough to demonstrate complicity. Each person understands that revealing some truth makes him/her vulnerable and this act of displaying vulnerability generates trust from others. Each person also knows that it is only fair that he/ she now carries a burden to help repair the damages brought about by the conflict as well as to ensure that no further communal violence takes place in Maluku.

In this case, truth is revealed in a limited manner and justice is observed in a futureoriented manner. This means that accounts of one's involvement in the conflict is only shared with a specific group of people with the specific purpose of gaining their trust. It also means that everyone knows that the way to absolve one's contributions to the violent past is to embrace a collective responsibility to repair damages and prevent future violence. This is grounded in an understanding that strict adherence to legal justice would put everyone behind bars. Such observance of "limited truth" and "future oriented justice" is considered to be most suited to the need of restoring normalcy in Maluku.

I suggest that the robustness of the desires for restoring normalcy over the desires for pursuing "blunt" truth and justice largely pertains to the vivid memories Malukans have of their pre-conflict life, which was laden with harmonious intergroup relations. In hundreds of interviews, both that of mine and those conducted for the Ambon Database 
Pilot Study and Ambon Database, Malukans talked enthusiastically about celebrating Christmas and Idul Fitri with members of the other faith group, about how close they were with their childhood friends and colleagues despite their religious difference, and about how, historically, Christians and Muslims in Maluku are basudara. They see the 1999 communal conflict as an exception, rather than the norm, to centuries of intergroup relations. This high regard toward memories of peace makes it costly for Christians and Muslims in Maluku to part ways, to pursue the truth and justice paths of reconciliation. Here, the Malukan experience stands out from similar cases of conflict such as in South Africa, Sri Lanka, and Northern Ireland, where violence and animosity had sustained over generations, hence blurring memories and repertoires of normalcy and of civilized relations between contending parties.

\section{Concluding remarks}

While being short of formal truth and justice procedures, the Malukan experience cannot be dismissed as a case in which reconciliation did not take place or did take place in a suboptimal manner. Reconciliation processes did happen in Maluku and are laden with lessons to learn from.

First, it establishes a strong case for taking an emic approach in studying reconciliation. It shows that when reconciliation is treated as vernacular practices, a handful of insights come to light: the various meanings of reconciliation, the shift of attitudes surrounding reconciliation, drivers of reconciliation, practices that would traditionally not be considered as reconciliation, etc. This paper has certainly not done any justice in fully presenting the richness of meanings and practices of rekonsiliasi in Maluku.

Second, it elucidates a less known path to reconciliation: interdependence. It brings attention to the four sites of interdependence, teases out how interdependence works, and underlines its performative aspects. In short, it proves that interdependence works. Nevertheless, more research needs to be conducted to identify the conditions under which interdependence work - does it work in settings other than communal violence, does it work when conflict is widespread throughout the country, does it work when one party to the conflict is seen as "migrants", and so on.

Third, it shows that the adoption of interdependence does not abandon truth and justice altogether. It uncovers how subjects settle the tension between the pragmatic need for normalcy and the moral imperatives of truth and justice, preventing us from taking a "black-and-white", "either-or" approach to the dilemma.

Lastly, the case of Maluku shows that, when selected by subjects themselves based on their understanding of the post-conflict situation they are in, interdependence can be as viable as truth commissions and trials in bringing about reconciliation.

\section{References}

Ackermann, A. (1994). Reconciliation as a peace-building process in postwar Europe: The Franco-German case. Peace \& Change, 19(3), 229-250.

Adam, J. (2009). The problem of going home: Land management, displacement, and reconciliation in Ambon. In Brauchler, B. (Ed.). Reconciling Indonesia: Grassroots agency for peace (pp. 138-154). Oxon: Routledge.

Adam, J. (2010). How ordinary folk became involved in the Ambonese conflict: Understanding private opportunities during communal violence. Bijdragen tot de Taal-, Land-en Volkenkunde, 166(1), 25-48.

Aladjai, E. (2013). Kei: Kutemukan cinta di tengah perang. Ciganjur-Jagakarsa: GagasMedia.

Ali-Fauzi, I. (2013, November 13). Ambon leads the way. Tempo, 4237, 58.

Allport, G.W. (1954). The nature of prejudice. Reading, MA: Addison-Wesley. 
Al Qurtuby, S. (2013). Peacebuilding in Indonesia: Christian-Muslim alliances in Ambon Island. Islam and Christian-Muslim Relations, 24(3), 349-367.

Avruch, K. (2010). Truth and reconciliation commissions: Problems in transitional justice and the reconstruction of identity. Transcultural Psychiatry, 47(1), 33-49.

Azca, M.N. (2006). In between military and militia: The dynamics of the security forces in the communal conflict in Ambon. Asian Journal of Social Sciences, 34(3), 431-455.

Barron, P., Azka, M.N., \& Susdinarjanti, T. (2012). After the communal war: Understanding and addressing post-conflict violence in Eastern Indonesia. Yogyakarta: CSPS Books.

Bartels, D. (1985). Pela alliances in the Central Moluccas and in the Netherlands: A brief guide for beginners. Retrieved from www. nunusaku.com/pdfs/Guide $\% 20$ for $\% 20$ Beginners.pdf

Bartels, D. (2003). Your God is no longer mine: Moslem-Christian fratricide in the Central Moluccas (Indonesia) after a halfmillennium of tolerant co-existence and ethnic unity. In Pannell, S. (Ed.). A state of emergency: violence, society, and the state in Eastern Indonesia (pp. 128-153). Darwin: Northern Territory Press.

Braithwaite, J., Braithwaite, V., Cookson, M., \& Dunn, L. (Eds.). (2010). Anomie and violence: Non-truth and reconciliation in Indonesian peacebuilding. Canberra: ANU E Press.

Braithwaite, J. \& Dunn, L. (2010). Maluku and North Maluku. In Braithwaite, J., Braithwaite, V., Cookson, M., \& Dunn, L. (Eds.). Anomie and violence: Non-truth and reconciliation in Indonesian peacebuilding (pp. 147-242). Canberra: ANU E Press.

Braeuchler, B. (Ed.). (2009). Reconciling Indonesia: Grassroots agency for peace. Oxon: Routledge.

Braeuchler, B. (2009b). Mobilizing culture and tradition for peace: Reconciliation in the Moluccas. In Brauchler, B. (Ed.). Reconciling
Indonesia: Grassroots agency for peace (pp. 97118). Oxon: Routledge.

Chapman, A.R. (2009). Approaches in studying reconciliation. In Van der Merwe, H., Baxter, V. \& Chapman, A.R. (Eds.). Assessing the impact of transitional justice: Challenges for empirical research. Washington, DC: U.S. Institute of Peace Press.

Chayes, A. \& Minow, M. (Eds.). (2003). Imagine coexistence: Restoring humanity after ethnic conflict. San Francisco: Jossey-Bass.

Daly, E. \& Sarkin J. (2007). Reconciliation in divided societies: finding common ground. Philadelphia: University of Philadelphia Press.

Dancy, G., Kim, H., \& Wiebelhaus-Brahm, E. (2010). The turn to truth: Trends in truth commission experimentation. Journal of Human Rights, 9, pp. 45-64.

Eriyanto. (2003). Media dan konflik Ambon. Jakarta: Kantor Berita $68 \mathrm{H}$.

Ernas, S. (2006). Pelaksanaan perjanjian Malino dan penyelesaian konflikMaluku (Unpublished MA thesis). Universitas Indonesia, Jakarta.

Fearon, J.D. \& Laitin, D.D. (1996). Explaining interethnic cooperation. The American Political Science Review, 90(4), 715-735.

Foundations of Qualitative Research in Education. Emic and Etic Approaches. Retrieved from http://isites.harvard.edu/icb/icb.do?keywor $\mathrm{d}=$ qualitative\&pageid=icb.page340911

Galtung, J. (2001). After violence, reconstruction, reconciliation, and resolution: Coping with visible and invisible effects of war and violence. In Abu-Nimer, M. (Ed.). Reconciliation, justice, and coexistence: Theory and practice (pp. 3-24). Lanham, MD: Lexington Books.

Galtung, J. (2005). Twelve creative ways to foster reconciliation after violence. Intervention, 3(3), 222-234.

Gardner Feldman, L. (1999). The principle and practice of 'reconciliation' in German foreign policy: relations with France, Israel, Poland and the Czech Republic. International Affairs, 75(2), 333-356. 
Hadar, I.A. (Ed.). (2000). Ambon damai lebe bae. Jakarta: IDe \& The British Council Jakarta. Hayner, P. B. (2002). Unspeakable truths: Confronting state terror and atrocities. New York: Routledge.

Headland, T. N., Pike, K. L., \& Harris, M., (Eds.) (1990). Emics and etics: The insider/ outsider debate. Frontiers of anthropology, v. 7. Newbury Park, Calif: Sage Publications. Hendriks, I.W.J. (2014). Ketika gereja bicara. In Manuputty, J., Salampessy, Z., Ali-Fauzi, I. \& Rafsadi, I. (Eds.). Carita orang basudara: Kisah-kisah perdamaian dari Maluku (pp. 129140). Ambon: Lembaga Antar Iman Maluku \& PUSAD Paramadina.

Herin, F.P. (2014, February 16). Kerukunan di Waraka menjadi model. Kompas Berbagi. Retrieved from http://berbagi.kompas. com/2015/02/11/kerukunan-di-warakamenjadi-model/

Hinton, A.L. (Ed.). (2010). Transitional justice: Global mechanisms and local realities after genocide and mass violence. Piscataway, NJ: Rutgers University Press.

Hinton, A.L. (2010a). Introduction: Toward an anthropology of transitional justice. In Hinton, A.L. (Ed.). Transitional justice: Global mechanisms and local realities after genocide and mass violence (pp. 1-22). Piscataway, NJ: Rutgers University Press.

Internal Displacement Monitoring Centre. (2011). Indonesia/Maluku and North Maluku: Support still needed for thousands of people ten years after their displacement. Geneva: IDMC.

International Crisis Group. (2000). Indonesia: Overcoming murder and chaos in Maluku (ICG Asia Report No. 10, December 19, 2000). Jakarta/Brussels: ICG.

Jesuit Refugee Services Indonesia. (2006). Boats of Hope. Yogyakarta: JRS Indonesia.

Jesuit Refugee Services Indonesia. (2013). Pengungsian berlarut-larut: Kaji kasus pengungsi internal di Vitas Barito, Passo, Ambon. Yogyakarta: JRS Indonesia.
Kelman, H.C. (2004). Reconciliation as identity change: A social-psychological perspective. In Bar-Siman-Tov, Y. (Ed.). From conflict resolution to reconciliation (pp. 111-124). New York: Oxford University Press.

Kriesberg, L. (2007). Reconciliation: Aspects, growth, and sequences. International Journal of Peace Studies, 12(1), pp. 1-21.

Kwon, H. (2006). After the Massacre: Commemoration and Consolation in $\mathrm{Ha} \mathrm{My}$ and My Lai. Berkeley and Los Angeles: California University Press.

Kymlicka, W. \& Bashir, B. (Eds.). (2008). The politics of reconciliation in multicultural societies. Oxford: Oxford University Press.

Laksono, P.M. \& Topatimasang, R. (Eds.). (2003). Ken sa faak: Benih-benih perdamaian dari Kepulauan Kei. Yogyakarta: Nen Mas Il \& INSIST Press.

Lederach, J. P. (1997). Building peace: Sustainable reconciliation in divided societies. Washington, DC: U.S. Institute of Peace Press.

Licklider, R. \& Bloom, M. (Eds.). (2007). Living together after the ethnic killing: Exploring the Chaim Kaufmann argument. UK: Routledge. Long, W.J. \& Brecke, P. (2003). Warandreconciliation: Reason and emotion in conflict resolution. Cambridge and London: MIT Press.

Malik, I. (2003). Resolusi dan kebenaran untuk Maluku. In Leatemia,R. (Ed.). Mematahkan kekerasan dengan semangat bakubae (pp. 11-37). Jakarta: YAPPIKA and Gerakan Bakubae Maluku.

Manuputty, J.F. (2011). Community based interreligious dialogue management: Christian and Muslim dialogue in Maluku province, Indonesia (Unpublished MA thesis). Hartford Seminary, Hartford.

Manuputty, J., Salampessy, Z., Ali-Fauzi, I. \& Rafsadi, I. (Eds.). (2014). Carita orang basudara: Kisah-kisah perdamaian dari Maluku. Ambon: Lembaga Antar Iman Maluku \& PUSAD Paramadina.

Meinema, E.H. (2012). Provoking peace: Grassroots peacebuilding by Ambonese youth 
(Unpublished MA thesis). Groningen: University of Groningen.

Olsen, T., Payne, L. \& Reiter, A. (2010). Transitional justice in balance: Comparing processes, weighing efficacy. Washington, DC: U.S. Institute of Peace Press.

Panggabean, S. R. (2004). Maluku: the challenge of peace. In Heijmans, A., Simmonds, N. \& Van de Veen, H. (Eds.). Searching for peace in Asia Pacific: An overview of conflict prevention and peacebuilding activities (pp. 416-437). Lynne Reinner Publishers.

Panggabean, R. (2014a). Mengapa kekerasan terjadi di Ambon tetapi tidak di Manado? Beberapa pelajaran menuju perdamaian berkelanjutan (Paper presented in Konferensi Kebudayaan Maluku I ( $1^{\text {st }}$ Maluku Cultural Conference), November 4-5, 2014).

Panggabean, R. (2014b). Penghindaran positif, segregasi, dan kerjasama komunal di Maluku. In Manuputty, J., Salampessy, Z., Ali-Fauzi, I. \& Rafsadi, I. (Eds.). Carita orang basudara: Kisah-kisah perdamaian dari Maluku (pp. 389-394). Ambon: Lembaga Antar Iman Maluku \& PUSAD Paramadina.

Panggabean, S.R. (2016). Konflik dan perdamaian etnis di Indonesia: Menjelaskan variasi (Unpublished dissertation). Yogyakarta: Universitas Gadjah Mada.

Pariela, T.D. (2008). Damai di tengah konflik Maluku (Unpublished dissertation). Salatiga: Universitas Kristen Satya Wacana.

Pettigrew, T.F. (1997). Generalized intergroup contact effects on prejudice. Personality and Social Psychology Bulletin, 23(2), 173-185.

Pettigrew, T.F. (1998). Intergroup contact theory. Annual Review of Psychology, 49, 65-85.

Popovski, V. \& Serrano, M. (Eds.). (2012). After oppression: Transitional justice in Latin America and Eastern Europe. Tokyo, New York, Paris: United Nations University Press.

Pouligny, B., Simon, C. \& Schnabel, A. (Eds.). (2007). After mass crime: Rebuilding states and communities. Tokyo: United Nations University Press.
Putnam, R.D. (2000). Bowling alone: The collapse and revival of American community. New York, NY: Simon \& Schuster.

R.S., Z. (2014). Jalan lain ke Tulehu. Yogyakarta: PT Bentang Pustaka.

Sandyarani, U. (2014). The effectiveness and prospect of religious peacebuilding: A study case analysis of Maluku (Unpublished BA thesis). Yogyakarta: Universitas Gadjah Mada.

Schelling, T. (1960). The Strategy of Conflict. Harvard University Press.

Sherif, M. (1958). Superordinate goals in the reduction of intergroup conflict. The American Journal of Sociology, 63(4), 349356.

Sidel, J.T. (2008). The manifold meanings of displacement: Explaining inter-religious violence, 1999-2001. In Hedman, E.E. (Ed.). Conflict, violence, and displacement in Indonesia (pp. 29-60). Ithaca: Cornell University Southeast Asia Program.

Skaar, E., Gloppen, S. \& Suhrke, A. (Eds.). (2005). Roads to reconciliation. Lanham, MD: Lexington Books.

Sluzki, C.E. (2010). The pathway between conflict and reconciliation: Coexistence as an evolutionary process. Transcultural Psychiatry, 47(55), 55-69.

Smith, D.L. (1989). The rewards of Allah. Journal of Peace Research, 26(4), 385-398.

Soselisa, S.E. (2007). Transformasi perilaku perempuan sebagai korban menjadi agen pembangun perdamaian: Studi kasus Ambon (Unpublished MA thesis). Yogyakarta: Universitas Gadjah Mada.

Staub, E. (2006). Reconciliation after genocide, mass killing or intractable conflict: Understanding the roots of violence, psychological recovery and steps toward a general theory. Political Psychology, 27(6), 867-895.

Tilly, C. (2008). Memorials to Credit and Blame. The Social Science Research Council. Retrieved from http://essays.ssrc.org/tilly/ creditblame 
Toisuta, H. (2014). Khotbah damai dari mimbar Masjid Al-Fatah. In Manuputty, J., Salampessy, Z., Ali-Fauzi, I. \& Rafsadi, I. (Eds.). Carita orang basudara: Kisah-kisah perdamaian dari Maluku (pp. 151-162). Ambon: Lembaga Antar Iman Maluku \& PUSAD Paramadina.

Van der Merwe, H., Baxter, V. \& Chapman, A.R. (Eds.). (2009). Assessing the impact of transitional justice: Challenges for empirical research. Washington, DC: U.S. Institute of Peace Press.

Van Klinken, G. (2001). The Maluku wars: Bringing society back in. Indonesia, 71, 1-26.

Van Klinken, G. (2007). Communal violence and democratization in Indonesia: Small town wars. New York: Routledge.

Van Klinkken, G. (2014). Ale rasa beta rasa: Menyusun sejarah bersama di Ambon. In Manuputty, J., Salampessy, Z., AliFauzi, I. \& Rafsadi, I. (Eds.). Carita orang basudara: Kisah-kisah perdamaian dari Maluku (pp. 1-11). Ambon: Lembaga Antar Iman Maluku \& PUSAD Paramadina.

Varshney, A. (2002). Ethnic conflict and civic life: Hindus and Muslims in India. New Haven: Yale University Press.

Wakano, A. (2014). Membangun perdamaian dalam kebuntuan dialog. In Manuputty, J., Salampessy, Z., Ali-Fauzi, I. \& Rafsadi, I. (Eds.). Carita orang basudara: Kisah-kisah perdamaian dari Maluku (pp. 199-210). Ambon: Lembaga Antar Iman Maluku \& PUSAD Paramadina.

White, R. K. (1984). Fearful warriors: A psychological profile of U.S.-Soviet relations. New York: Free Press.

Willis, Jerry W. (2007). Foundations of qualitative research: Interpretive and critical approaches. Thousand Oaks, CA: Sage.

Yin, Robert K. (2010). Qualitative research from start to finish. New York: The Guilford Press. 